\title{
A PERSONAL Word
}

\section{Francis Cooke QC}

I am very pleased to accept the Editors' invitation to contribute to this issue of the Law Review. It provides me with an opportunity to record some thoughts on a man who has hugely influenced my life. There are, however, some difficulties. One is in striking the right balance between a personal contribution and an article worthy of publication in a distinguished Law Review. Another is the desirability of the son not overdoing the praise of his famous father. But the reader will, I hope, excuse some personal content, and it may not be completely out of place in this publication to be complimentary. So, in an attempt to provide something of value notwithstanding these difficulties, I will endeavour to describe a personal attribute of my father, and illustrate how it influenced his approach to legal problems, and to judging.

To say my father had a love of words is an understatement. He was, in fact, completely fascinated by them. Whether he was stroking his sideburns (mid 70s), gnawing his handkerchief (80s and 90s) or simply sitting with closed eyes (throughout), it was words, and the ideas they conveyed, that were completely occupying him. The product of the concentration could sometimes be devastating. For counsel an argument could be crushed, or taken beyond wildest dreams. At home the same approach could result in a sparkling joke, or an insight into another's personality. In either environment the ability to express ideas with an attractive use of language could capture the listener. His use of words made what he said, or wrote, more attractive, and therefore persuasive. The verbal formulations seemed almost impossible to contradict. His carefully crafted sentences could be both authoritative and highly entertaining.

Any need for proof of this obsession with words, and with meanings, can be found in my father's pursuits outside of the law. He had a love of great literature, but above all of Shakespeare. And here it was partly Shakespeare's use of language and of double meanings that attracted him. There would always be a pocket version of one of the plays tucked into a jacket pocket. My visits to Stratfordupon-Avon with my parents will remain among the fondest of memories. Equally, cryptic crosswords, particularly those appearing in The Times, were a favourite pastime. It would be almost impossible not to find some crossword on the go. With cryptic crosswords it was the word play, and the more overt double meanings that appealed. Imagine my father's excitement when he began doing The Times cryptic crossword one morning shortly before his fourth Hamlyn lecture to find that the 
answers to at least seven of the clues were direct references to his upcoming lecture. ${ }^{1}$ He was very proud of once winning The Times cryptic crossword competition, and the prize (an atlas of the world) is one of the family's treasured possessions.

In many ways the attributes I have described are more closely associated with the skills of an advocate, rather than those of a judge. This was something of which he was conscious. He once identified his father, the more orthodox lawyer, as better suited to the judicial role and there do appear to have been important differences between their approaches. For RB Cooke "a few careful and concise but forceful submissions ... sometimes alter the result of a case. Sometimes even a single striking sentence does the trick". ${ }^{2}$ On the other hand PB Cooke saw "all kinds of possibilities in a case, and on occasion a Judge would think that [his] argument was overladened". ${ }^{3}$ But the advocate's skill is not necessarily inconsistent with the judicial function. That is not just because a powerful judgment can involve the advocacy of new ideas. The ability to recognise how words persuade not only leads to legal propositions being put in an effective way, but enables the identification of situations where words are obscuring underlying principle, and disguising the right answer. An analysis of my father's judicial and extra-judicial work demonstrates that he was frequently concerned with attempts to explain why particular verbal formulations which had become reasonably well settled were hiding rather than exposing the underlying principle.

\section{AN UNREASONABLE TEST}

The best example of this point is Wednesbury unreasonableness. ${ }^{4}$ In this case Lord Greene MR indicated that a court could interfere by way of judicial review if the decision-making authority came "to a conclusion so unreasonable that no reasonable authority could ever have come to it". ${ }^{5}$ Thus was borne a phrase that has stayed in the mind of lawyers since that time. Indeed, arguably it is the most well known judicial review phrase for lawyers in New Zealand and the United Kingdom it has stuck in the collective conscious. It is doubtful, however, that Lord Greene was aware that he was making his most famous judicial utterance. The judgment records that he felt the decision did not require reference to authority, and it would seem that the defendant's counsel was not called

1 See the reference in Lord Cooke of Thorndon Turning Points of the Common Law (Sweet \& Maxwell, London, 1997) 63.

2 "Court of Appeal President: An interview with Sir Robin Cooke" (1986) NZLJ 170, 173.

3 A slightly adverse comment in an otherwise positive assessment by Sir David Smith in R B Cooke (ed) Portrait of a Profession: The Centennial Book of the New Zealand Law Society (AH \& AW Reed, Wellington, 1969) 131. Interestingly the same work describes FH Cooke, one generation further back, as having "... the faculty of presenting the facts of the case, and the necessary applicable law, in the minimum of words" (326).

4 Associated Provincial Picture Houses Ltd v Wednesbury Corporation [1948] 1 KB 223 (CA).

5 Ibid, 234 Lord Greene MR. 
upon. ${ }^{6}$ Nevertheless it is a famous decision, and a famous phrase, and the case is described by some as one of the "bedrocks of our modern administrative law". ${ }^{7}$ But it was the dicta that my father most disliked.

This dislike was most evident from his extra judicial writings. He described the test as "a distracting circumlocution". ${ }^{8}$ As a test it did little more than reinforce the need for judicial deference. The court was being reminded that it should be slow to substitute its views on the merits for those of the body charged with the decision making exercise. But it did little more than provide an indirect reminder of this need - there is nothing in the words that provide any direct content. It is a verbal expression of an almost emotional nature. Neither is there any appreciation that the nature of judicial deference will ultimately depend on the legal subject matter.

My father saw no need to be reminded of the concept of judicial deference by a kind of verbal trick. Judicial deference was appropriately considered directly. The function of the court is to ensure that the decision making body has made a decision reasonably open to it given the power that it has been given. By focussing simply on what is reasonably open to the deciding body, the emphasis is squarely on the court's function - that is to ensure a decision is made in accordance with law. If anything, the Wednesbury formulation suggests judicial review has something to do with the court's personal views on a topic, with the court being permitted to interfere when the judge finds the decision highly disagreeable. The judicial review exercise has nothing to do with the judge's personal views on the subject matter. The verbal formulation is thereby potentially misleading. In one paper, my father described his view in the following way: ${ }^{9}$

Lastly I come back to reasonableness: the merits, substance, how far will the courts go? ... Let it be clear that no one, anywhere, suggests that the courts can substitute their discretion for that of the administrative authority, or intrude into policy formation and application where the policy is consistent with statute. Even the administrator's view of the facts is at least highly likely to be accepted if reasonably open: for it is doubtful whether the concept of jurisdictional fact has validity any longer. The concern is to check that the decision of the Minister or other authority is one that could reasonably be reached on the facts and in the light of the relevant law. It is no severe test; to refrain from insisting even on compliance with this generous test would be to abandon proper judicial responsibility. Often lawyers

$6 \quad$ See the comments of Sir John Laws "Wednesbury" in Christopher Forsyth and Ivan Hare (eds) The Golden Metwand and the Crooked Cord, Essays on Public Law in Honour of Sir William Wade (Clarendon Press, Oxford, 1998) 185.

7 Ibid, 186.

8 Sir Robin Cooke "The Struggle for Simplicity in Administrative Law" in M Taggart (ed) Judicial Review of Administrative Action in the 1980s (Oxford University Press, Auckland, 1986) 14-15.

9 Sir Robin Cooke "Administrative Law Trends in the Commonwealth" in Visu Sinnadurai (ed) The Sultan Azlan Shah Law Lectures: Judges on the Common Law (Thompson Sweet \& Maxwell Asia, Kuala Lumpur, 2004) 105, 128. 
round the world speak of Wednesbury unreasonableness. I venture to think that there is nothing arcane or special about the subject requiring the geographical epithet. The duty is simply to act reasonably, that is to say in accordance with reason.

In a later paper more directly focussing on Wednesbury, he said this: ${ }^{10}$

Lord Greene's Wednesbury criteria require the administrative authority to direct itself properly in law. Greater attention to that requirement might even compensate to a significant extent for the weakness of the unreasonableness criterion as formulated by Lord Greene. Not infrequently a decision subject to judicial review may be one which a reasonable authority could take, looking at the subject-matter in the abstract and without regard to the authorising statute. The Wednesbury case itself might have been in that category. The condition there in question prohibited the attendance of children under 15 at cinemas on Sundays, making no exception for children accompanied by their parents. To some perfectly reasonably people that degree of paternalism on the part of the local council might seem sensible rather than patronising; whereas it is far from self-evident that the Act prescribing the cinema licensing power ought to have been construed as authorising the local authority to (in effect) supplant the prerogative of parents. If film-going parents with children under 15 constituted a special community hazard in Wednesbury, the court was entitled to evidence to that effect.

Some comments were a little more critical. In the same paper he observed that "Lord Greene was a most gifted Judge; in this instance the masterly and authoritative manner of his judgment may have tended to obscure what can now be seen as the superficiality of some of the matter", ${ }^{11}$ and he ended another paper by saying "by and large administrative law is on the right road, as is shown by the fact that until now, at the very end, this lecture has required not a single utterance of word Wednesbury". ${ }^{12}$

Judicial discipline prevented any of these more pointed remarks appearing in a judgment. In Webster $v$ Auckland Harbour Board he had observed that "unvarnished adherence" to unreasonableness in its ordinary sense avoided the difficulties caused by the semantics inherent in the "Wednesbury" test, ${ }^{13}$ but it was fairly late in the piece that he made the most critical comments about Wednesbury in a decision of the House of Lords. He once told me that he particularly enjoyed his judicial period in the United Kingdom because he did not feel the same responsibility to provide judgments as he had as President of the New Zealand Court of Appeal, and felt he only needed to

10 Sir Robin Cooke "Damnosa Hereditas" in Judicial Review An International Perspective, Liber Amicorum in Honour of Lord Slynn of Hadley (Kluwer Law International, London, 2000) Vol 2, 237, 240.

11 Ibid, 237.

12 Sir Robin Cooke "The Road Ahead for the Common Law" (Commonwealth Lecture, British Institute of International and Comparative Law, October 2003).

13 Webster v Auckland Harbour Board [1987] 2 NZLR 129, 132 (CA) Cooke P. 
write a judgment when he truly felt he could make a contribution. It is likely that he would have included $R$ (Daly) v Home Secretary ${ }^{14}$ in that category. Here he said: ${ }^{15}$

The other matter concerns degrees of judicial review. Lord Steyn illuminates the distinction between 'traditional' (that is to say in terms of English case law, Wednesbury) standards of judicial review and higher standards under the European Convention or the common law of human rights. As he indicates, often the results are the same. But the view that the standards are substantially the same appears to have received its quietus in Smith and Grady v United Kingdom (1999) 29 EHRR 493 and Lustig-Prean and Beckett $v$ United Kingdom (1999) 29 EHRR 548. And I think that the day will come when it will be more widely recognised that Associated Provincial Picture Houses Ltd v Wednesbury Corpn [1948] 1 KB 223 was an unfortunately retrogressive decision in English administrative law, in so far as it suggested that there are degrees of unreasonableness and that only a very extreme degree can bring an administrative decision within the legitimate scope of judicial invalidation. The depth of judicial review and the deference due to administrative discretion vary with the subject matter. It may well be, however, that the law can never be satisfied in any administrative field merely by a finding that the decision under review is not capricious or absurd.

The reader will have noticed that the son has found his father's views agreeable ones. But the agreement may not be complete. To the extent that cases such as Daly endorse the idea that the intensity of judicial review should overtly change with the subject matter, the son may depart company. There is no such thing as degrees of illegality. The idea that in some cases a court tries harder to see if there is any unlawfulness seems inconsistent with the judicial function. It is apparent that in some cases courts will be better placed to identify illegality because of the subject matter. In the area of human rights, for example, the courts have the expertise to identify the legal limits of executive action. There is no need for any deference. Moreover, the importance of such fundamental rights may simply arise from the correct interpretation of the law, rather than from the adoption of more "intense" scrutiny. Even in quite technical areas, where the specialisation of the deciding body seems to be important, the statute may still require the court itself to descend into the technical detail, the merits if you like, to make sure the law is being applied. ${ }^{16}$ Notions of intensity simply obscure the real task, which is to ensure the law is being followed.

$14 R$ (Daly) v Home Secretary [2001] 2 AC 532 (HL). See also $R v$ Chief Constable of Sussex ex parte International Traders Ferry Ltd [1999] 1 All ER 129, 157, where the test is described as an "admonitory circumlocution".

15 Ibid, 549 Lord Cooke.

16 So, for example, the Court of Appeal in Squid Fishery Management Co Ltd v Minister of Fisheries (13 July 2004) CA 39/04 Hammond, William Young and O'Regan J set aside a decision on sea lion mortality rates in the squid fishery because the scientific model used by the Minister's advisers did not conform with the information requirements of the Fisheries Act 1996. 
As a practitioner in the area, it has become apparent that it is very fashionable to have a debate in each judicial review case on what the standard of review is. This seems to be a further distraction in an area where simplicity should be the objective. This is, after all, the "struggle". ${ }^{17}$ But I digress, and in any event it is not altogether clear that my father directly endorsed the intensity of review concept, rather than welcoming any new path that helped the courts get out of the Wednesbury rut. He did tend to have the longer term in mind.

\section{OTHER VERBAL DISTRACTIONS}

The linguistic sins of the law were not limited to Wednesbury unreasonableness. There were many other examples where my father thought that the words were getting in the way of a true understanding of principle. That was not limited to the field of judicial review, although in that area in particular much of the jurisprudence seems to be devoted to the creation of categories with particular labels, followed by endless debate on what they really mean. It is frightening to think how much intellectual time has been spent around the common law world by people exploring the concept of "nullity", or debating the difference between what is "void" or what is "voidable". ${ }^{18}$ Once it was established that judicial review was available "on the face of the record", we agonised on what the record was. ${ }^{19}$ My father was not the first or the only advocate of the abandonment of this masochism. But it was nevertheless his favourite cause. His desire was to "avoid technical and apparently exact (yet deceptively so) terms such as void, voidable, nullity, ultra vires. Weight is given rather to the seriousness of the error and all the circumstances of the case". ${ }^{20}$

In the areas of tort law, and in particular negligence, the desire was to strip away labels that could mislead. Thus in his third Hamlyn lecture he dismissed "proximity" as providing any help as a guide to the duty of care question - "the term itself is currently much employed but gives no help at all in ascertaining whether the courts would regard the relationship as close enough". ${ }^{21}$ And he felt the same about the word "incremental" which he described as "another judicially 'in' word". The use of this term involved a "... suggestion that an increment is only a very little addition; but, if so, this is as unsound etymologically as it would be if intended to reflect the way in which the common law

17 See the title of Paul Rishworth (ed) The Struggle for Simplicity in the Law: Essays for Lord Cooke of Thorndon (Butterworths, Wellington, 1997).

18 I can't help but noticing Christopher Forsyth's paper in The Golden Metwand and the Crooked Cord Essays on Public Law in Honour of Sir Williams Wade, above n 6, 141 is titled "The Metaphysic of Nullity Invalidity, Conceptual Reasoning and the Rule of Law". He concludes "Nullity ... is one of the foundations of administrative law". By contrast, my father's paper in the same publication is entitled "The Discretionary Heart of Administrative Law" (203).

19 See GDS Taylor Judicial Review (Butterworths, Wellington, 1991) paras 14.10 -14.11.

AJ Burr Ltd v Blenheim Borough [1980] 2 NZLR 1, 4 (CA) Cooke J.

21 Robin Cooke "The Temptation of Elegance Resisted" in Turning Points of the Common Law, above n 1, 48, 54. 
has been developed ...". ${ }^{22}$ Other examples of this approach can be found in other fields of law indeed in most fields of law that he encountered.

His critics were minded to say that his approach tended to make the law less certain, as too much was left to the individual views of the court, and to judicial discretion. The court's decisions were accordingly too difficult to predict. Yet it is far from clear that this is really so, and it certainly was not the intention. The whole objective of the struggle for simplicity was to make the law easier to understand. The kind of concepts that he rebelled against did not create certainty at all, particularly when it was uncertain exactly what they meant, or what the exceptions to them were. And the critics may not have properly taken into account that the desire for clear cut and readily understandable principles in the commercial law area was part of the goal. Thus the first of the four cases he chose in his four Hamlyn lectures as being turning points in the law was Salomon $v \mathrm{~A}$ Salomon \& Co Ltd, which recognised the importance of the separate legal personality of companies. $^{23}$ And in fields such as tort, he was of the view that negligence should not create confusion by creating remedies that were inconsistent with established common law rules, such as those in defamation. ${ }^{24}$ So the criticism seems unwarranted, or at best needs significant refinement.

But my main point is to demonstrate how significant the almost obsessive interest in language was to my father's approach as a judge. In the end judges are people like everybody else, and their personalities will frequently explain their judicial approach.

\section{CONSTITUTIONAL MEASURES}

The debates surrounding the sovereignty of Parliament need also to be mentioned in this context. The view that "some common law rights presumably lie so deep that even Parliament could not override them" 25 has been the subject of considerable discussion, and has been a theme of the annual Robin Cooke lecture at Victoria University. Whilst some see the view as an undemocratic claim for power by the courts, in the end the ambition was to keep each branch within proper bounds, including the courts. Words, and the concepts they conveyed were not to be used in an attempt to distort the underlying balance. The word "sovereignty" itself derived its meaning from judicial interpretation. When the concepts were recorded in the terms of written constitutional instruments, my father naturally favoured Lord Wilberforce's instruction to adopt a "generous

22 Ibid, 55.

23 Ibid, 1 "A Real Thing". A view expressly advanced judicially in Trevor Ivory Ltd v Anderson [1992] 2 NZLR 517 (CA).

24 South Pacific Manufacturing Co Ltd v New Zealand Security Consultants \& Investigations Ltd [1992] 2 NZLR 282; Bell Booth Group Ltd v Attorney-General [1989] 3 NZLR 148. Compare Spring v Guardian Assurance PLC [1995] 2 AC 296.

25 Taylor v NZ Poultry Board [1984] 1 NZLR 394 at 398. 
interpretation avoiding what has been called 'the austerity of tabulated legalism"', 26 which he described as a statement "now evidently destined for judicial immortality". ${ }^{27}$ But whilst disliking technical or pedantic interpretations, he also disliked complex interpretations that departed from the natural meaning of the words, even if employed to advance the power of the courts in relation to the executive.

His views on issues affecting the Indian Constitution illustrate the true philosophy, as well as the personal attributes that I have been seeking to describe. In three cases the Indian Supreme Court addressed the question of the powers of the Indian Government in relation to the appointment of Judges. In the second such case JS Verma J, for a majority of five Judges, quoted Isabella's plea in Shakespeare's Measure for Measure to justify an interpretation giving greater power to the court: ${ }^{28}$

$\mathrm{O}$, it is excellent

To have a giant's strength, but it is tyrannous

To use it like a giant.

Thus absolute, or sovereign, power of the executive was resisted. But my father was not persuaded, and the reference to Shakespeare was irresistible. He thought that the court had used artificial interpretive techniques, and in an article entitled "Making the Angels Weep" referred to another section of Isabella's speech to make his point: ${ }^{29}$

But man, proud man,

Dressed in a little brief authority,

$\cdots$

Plays such fantastic tricks before high heaven

As makes the angels weep ...

He made the point more directly in the following way: ${ }^{30}$

It seemed to me, however - as I believe it has seemed to many other lawyers both inside and outside India - that the majority judgement, admirably motivated though it was by devotion to the rule of law,

26 Minister of Home Affairs v Fisher [1980] AC 319, 328.

27 MOT v Noort [1992] 3 NZLR 260, 268.

28 Supreme Court Advocates-On-Record-Association v Union of India (1994) AIR, SC 268.

29 Robin Cooke "Making the Angels Weep" in B N Kirpal, Ashok H Desai, Gopal Subramanium, Rajeev Dhavan and Raju Ramachandran (eds) Supreme But Not Infallible, Essays in Honour of the Supreme Court of India (Oxford University Press, Oxford, 2000) 97, 98.

30 Ibid. 
made free with the actual provisions of the Constitution. A layman might have felt bewildered by something like a sleight of hand...

In In re Special Reference 1 of $1988^{31}$ the Indian Supreme Court confronted these interpretative issues for a third time, adopting a similar general approach as the second case. And in a further article, "Where Angels Fear to Tread" the doubts were now expressed with reference to Alexander Pope rather than Shakespeare. He said: ${ }^{32}$

All in all, the opinion of the Supreme Court in the third Judges case must be one of the most remarkable rulings ever issued by a supreme national appellate court in the common law world. Since, in some respects, I have had to voice respectful doubts about the soundness of the constitutional foundations of that opinion, let me end on the happier note by saying that my admiration for the Supreme Court in its ordinary work, particularly in the field of human rights, is in no way abated.

A third paper grew the relevant themes together. In presenting his contribution to former Indian Attorney-General Soli Sorabjee, he returned to Shakespeare, with the papers title - "How Like an Angel" - taken from Hamlet. ${ }^{33}$ In drawing these themes together he said: ${ }^{34}$

Although the contrary became fashionable, particularly because of Dicey, today constitutional scholars may increasingly be reluctant to answer current issues by appeals to some doctrine of sovereignty. "The sovereignty of Parliament" is to catchphrase beloved of some sections of the media and some politicians; incongruously it got into some Supreme Court Act in New Zealand. But it does not survive in-depth analysis. In international law there are said to be sovereign states, yet even that concept is gradually being undermined by developments such as the European Union and devolution within the United Kingdom. Within a national polity the sovereignty concept may be largely replaced by one of interaction, of checks and balances, of some degree of competition....

And he concluded: 35

Room exists and is utilised for judicial creativeness; but it is balanced by judicial deference to the founding charter...

31 In re Special Reference 1 of 1988 (1998) 7 SCC 739.

32 Robin Cooke "Where Angels Fear to Tread" in Kirpal and others, above n 29, 105.

33 Robin Cooke "How Like an Angel" in MC Sharma and R Ramachandran Constitutionalism Human Rights and the Rule of Law Essays in Honour of Soli J Sorabjee (Universal Law Publishing Co Limited, Delhi, 2005) 34.

34 Ibid, 37.

35 Ibid, 47 
The overall truth is that the Constitution contains a melange of powers. No single institution is even nearly omnipotent. There is no sovereign. A jurist who search for one would be expending energies idly. I think that this will probably always be so in a democracy.

The three "angel" papers capture both the style and the substance. The law should be interpreted in straightforward terms. Words should not be used to disguise true meaning, but to accurately to capture it. Even with unwritten constitutions, the key concepts will be expressed in words such as "sovereignty", but the very use of such terms should not lead to the principles being obscured.

\section{THE FIRST AND LAST WORDS}

Just over 50 years separate my father's first and last published contributions. Both were to the Law Quarterly Review. A comparison of the two articles reveals that his style and ultimate approach was unchanged. In the first, the young Cambridge scholar dealt with the conflicting authorities on the approach that an appeal court should take to cases where errors had occurred in a criminal trial, and whether the trial should be treated as being a nullity. ${ }^{36}$ In proposing his solution to the issue, he sought to find the "single striking sentence" that captured rather than obscured the important principle: ${ }^{37}$

The authorities in their present state seem to provide no touchstone for determining when an irregularity is so serious as to cause mistrial. The extent of the power placed in the hands of the Court of Criminal Appeal by the decision of the House of Lords in Crane $v$ Director of Public Prosecutions remains obscure; and its clarification must await some decisive and constructive judgment. Perhaps a basis for the development of the law may be found simply in a phrase falling from Lord Sumner in the case of Crane and echoed by Lord Atkin and Lord Goddard CJ in the cases of Ras Behair Lal and Neal respectively. It might be said that an irregularity causes a mistrial if its effect is 'to deprive an accused person of the protection given by essential steps in criminal procedure.' In the three cases cited these or similar words were used for the immediate purpose of explaining why a conviction must be quashed; but possibly they might also be used for the further purpose of explaining when the Court of Criminal Appeal may in its discretion order a venire de novo on the ground of mistrial. Such a definition is somewhat elastic; but ... there are advantages in refraining from great particularity in defining the powers of such a court ...

Fifty years later he was not quite so circumspect in suggesting that the answer could be found in straightforward language. I recall seeing a draft of his last article, later published in the April 2006 Law Quarterly Review. It was handwritten, as almost everything he produced was. He was not well, but this had not curtailed either his faculties or his abilities. In criticising the House of Lords'

36 Robin Cooke "Venire De Novo" (1955) 71 LQR 100.

37 Ibid, 128. 
decision in Jackson $v$ Attorney-General, ${ }^{38}$ he contended that their Lordships had failed to apply the plain meaning of the words of an Act of Parliament. Where the Indian Supreme Court had been too bold, the Judicial Committee of the House of Lords had been too timid. An Act of 1911 set out a procedure that allowed the House of Commons to pass legislation without the consent of the House of Lords, and given that the procedure was expressed in conditional language, the procedure had not been followed if the conditions were not satisfied - "the point is a straightforward one of ordinary statutory construction or interpretation". ${ }^{39} \mathrm{He}$ concluded this article with a passage which characterised his ability to use language effectively, and attractively, and with the touch of the double meanings that he so enjoyed. They were, and are, appropriate last words: ${ }^{40}$

The immediate outcome of Jackson v Attorney-General is not surprising. The controversy generated by the Hunting Bill was sharply and deeply divisive, socially and otherwise. To decline to allow the majority of the House of Commons to have their way would have been a most daunting step for the Appellate Committee of the House of Lords. It would have been open in the media and hence in discussion in 'the populace' to misrepresentation as amounting to judicial frustration of the will of the elected chamber, rather than to application of the existing constitutional law. I do not suggest that these considerations dictated the outcome. Undoubtedly the British courts would not have shrunk from invalidating the Hunting Act if they had no reasonable alternative. Fortunately, for public relations, an alternative presented itself which can fairly be called reasonable, even if vulnerable for the foregoing reasons.

Discretion is the better part of valour. A retreat may represent wisdom rather than timidity. It is in that light that history may well see the case of Jackson. The British Constitution is still one of checks and balances. But the balance has been significantly changed, and the checks on the popular assembly as constituted for the time have been significantly diminished. Constitutionalism has taken quite a heavy, if foreseeable, blow.

38 Jackson v Attorney-General [2005] UKHL 56.

39 Robin Cooke "Constitutional Retreat" (2006) 122 LQR 224, 228.

40 Ibid, 231. 
(2008) 39 VUWLR 